\title{
Scale- and taxon-dependent patterns of plant diversity in steppes of Khakassia, South Siberia (Russia)
}

\author{
Mariya A. Polyakova ${ }^{1}$ Iwona Dembicz ${ }^{2}$ Thomas Becker ${ }^{3}$. \\ Ute Becker $^{4}$ - Olga N. Demina ${ }^{5}$ - Nikolai Ermakov ${ }^{1}$. \\ Goffredo Filibeck $^{6} \cdot$ Riccardo Guarino $^{7} \cdot$ Monika Janišová $^{8}$. \\ Renaud Jaunatre $^{9,10} \cdot$ Lukasz Kozub $^{2}$ - Manuel J. Steinbauer ${ }^{11}$. \\ Kohei Suzuki $^{12} \cdot$ Jürgen Dengler $^{13,14}$
}

Received: 31 October 2015/Revised: 22 March 2016/Accepted: 31 March 2016/

Published online: 13 April 2016

(C) The Author(s) 2016. This article is published with open access at Springerlink.com

\begin{abstract}
The drivers of plant richness at fine spatial scales in steppe ecosystems are still not sufficiently understood. Our main research questions were: (i) How rich in plant species are the natural steppes of Southern Siberia compared to natural and semi-natural grasslands in other regions of the Palaearctic? (ii) What are the main environmental drivers of the diversity patterns in these steppes? (iii) What are the diversity-environment relationships and do they vary between spatial scales and among different taxonomic groups?
\end{abstract}

Communicated by Didem Ambarl1.

Electronic supplementary material The online version of this article (doi:10.1007/s10531-016-1093-y) contains supplementary material, which is available to authorized users.

Mariya A. Polyakova

galatella@mail.ru

$\triangle$ Iwona Dembicz

iwodem@op.pl

1 Laboratory of Ecology and Geobotany, Central Siberian Botanical Garden, Russian Academy of Science, Siberian Branch, Zolotodolinskaya Str., 101, Novosibirsk, Russia 630090

2 Department of Plant Ecology and Environmental Conservation, Faculty of Biology, University of Warsaw, Al. Ujazdowskie 4, 00-478 Warsaw, Poland

3 Department of Geobotany, Faculty of Regional and Environmental Sciences, University of Trier, Behringstr. 21, 54296 Trier, Germany

4 Green School in the Botanic Garden, University of Mainz, Anselm-Franz-von-Bentzel-Weg 9b, 55128 Mainz, Germany

5 Karachay-Circassian State University, Lenina Street 29, Karachaevsk, Russia 369200

6 Department of Agricultural and Forestry Sciences (DAFNE), University of Tuscia, 01100 Viterbo, Italy

7 Department STEBICEF - Botanical Unit, University of Palermo, Via Archirafi 38, 90123 Palermo, Italy

8 Institute of Botany, Slovak Academy of Sciences, Ďumbierska 1, 97411 Banská Bystrica, Slovakia 
We sampled the steppe vegetation (vascular plants, bryophytes and lichens) in Khakassia (Russia) with 39 nested-plot series $\left(0.0001-100-\mathrm{m}^{2}\right.$ plot size) and 54 additional $10-\mathrm{m}^{2}$ quadrats across the regional range of steppe types and measured various environmental variables. We measured $\beta$-diversity using $z$-values of power-law species-area relationships. GLM analyses were performed to assess the importance of environmental variables as predictors of species richness and $z$-value. Khakassian steppes showed both high $\alpha$ - and $\beta$-diversity. We found significant scale dependence for the $z$-values, which had their highest values at small spatial scales and then decreased exponentially. Total species richness was controlled predominantly by heat load index, mean annual precipitation, humus content and soil skeleton content. The positive role of soil $\mathrm{pH}$ was evident only for vascular plant species richness. Similar to other studies, we found that the importance of environmental factors strongly differed among taxonomic groups and across spatial scales, thus highlighting the need to study more than one taxon and more than one plot size to get a reliable picture.

Keywords Biodiversity · Bryophyte - Environmental factor · Lichen · Species-area relationship $\cdot$ Species richness

\section{Introduction}

Temperate grasslands are the most diverse plant communities globally with regard to vascular plants for plot sizes below $100 \mathrm{~m}^{2}$ (Wilson et al. 2012). Except for two examples in Argentina, all known world-records of plant species richness of grasslands are located in the Palaearctic realm. While the Palaearctic steppes with an original extent of 13 million $\mathrm{km}^{2}$ form the largest grassland biome on Earth (Wesche and Treiber 2012), the documented extremely diverse grasslands are all located within the nemoral biome of Europe, meaning that they are semi-natural communities that have emerged and are maintained by low-intensity land use (Dengler et al. 2014; Roleček et al. 2014). It is challenging to understand why semi-natural analogues to the natural steppe vegetation should host higher species densities than the natural steppes. However, this finding could be an artefact caused by the disproportionally higher number of studies on plant diversity in Palaearctic seminatural grasslands (e.g. Löbel et al. 2006; Merunková et al. 2012; Janišová et al. 2014;

$9 \quad$ Université d'Avignon et des Pays de Vaucluse, Institut Méditerranéen de Biodiversité et d'Ecologie (UMR CNRS/IRD 7263/237), IUT, Site, Agroparc, BP 61207, 84911 Avignon Cedex 9, France

10 Université Grenoble Alpes, Irstea, UR EMGR, 2 rue de la Papeterie, BP 76, 38402 St-Martin-d'Hères, France

11 Section Ecoinformatics \& Biodiversity, Department of Bioscience, Aarhus University, Ny Munkegade 116, 8000 Aarhus, Denmark

12 Graduate School of Environmental Studies, Nagoya University, D2-2(510), Furo-cho, Chikusa-ku, Nagoya 464-8601, Japan

13 Plant Ecology, Bayreuth Center of Ecology and Environmental Research (BayCEER), University of Bayreuth, Universitätsstr. 30, 95447 Bayreuth, Germany

14 German Centre for Integrative Biodiversity Research (iDiv) Halle-Jena-Leipzig, Deutscher Platz 5e, 04103 Leipzig, Germany 
Turtureanu et al. 2014; Palpurina et al. 2015; reviews by Dengler 2005; Dengler et al. 2014) than in natural steppes (e.g. Chytrý et al. 2007; Mathar et al. 2016; Kuzemko et al. 2016 , in this issue). Indeed, there have also been sporadic reports of species richness close to the global maxima from natural meadow steppes (Walter and Breckle 1986; Lysenko 2007), which might indicate that more comprehensive studies could find hotspots of smallscale diversity also in natural steppes.

Palaearctic steppes form one of the largest biomes on earth. They are very diverse concerning the physical habitat and floristic composition, ranging from the relatively mesic steppes of Eastern Europe to dry-continental steppes (including semi-desert and desert steppes) widely distributed across the Asian continent (Lavrenko et al. 1991; Korolyuk 2002). Many steppes were used for nomadic pastoralism over centuries or even millennia. Over the last few decades, however, vast areas formerly covered by natural grasslands were converted into arable fields (Hoekstra et al. 2005; Smelansky and Tishkov 2012; Kuzemko et al. 2016, in this issue). Today, Asian steppes are among the most threatened ecosystems of the world (Henwood 1998; Wesche and Treiber 2012). Studying patterns and processes of Eurasian steppe biodiversity is of great scientific relevance, because they may represent a direct continuation (or at least a modern analogue) of the Pleistocene glacial steppe that was widespread across the Palaearctic, and from which much of the floristic composition of present-day secondary grasslands is derived (Bredenkamp et al. 2002; Chytrý et al. 2007; Kuneš et al. 2015; Pokorný et al. 2015).

We still lack a general theory of the drivers of plant richness at fine spatial scales in steppe and grassland ecosystems. The environmental variables most frequently analysed to explain richness patterns at plot scale in grasslands and steppes include soil pH (e.g. Löbel et al. 2006; Chytrý et al. 2007; Palpurina et al. 2015), soil fertility (e.g. Becker and Brändel 2007), grazing intensity and land use (e.g. de Bello et al. 2007; Turtureanu et al. 2014; Mathar et al. 2016, in this issue), elevation (Austrheim 2002), microrelief (Löbel et al. 2006; Deák et al. 2015), topographic wetness and soil humidity (Moeslund et al. 2013; Mathar et al. 2016 in this issue) and climate (Chytrý et al. 2007; Palpurina et al. 2015). The effect and importance of these factors, however, significantly varied between studies. For instance, soil pH can have a positive (Kuzemko et al. 2016 in this issue and literature cited therein; see also Chytrý et al. 2010), negative (Chytrý et al. 2007), hump-shaped (Mathar et al. 2016 in this issue) or no effect (Cachovanová et al. 2012) on plant species richness of dry grasslands. Another example is the role of management and disturbance factors, which were found to be the most explanatory variables in some studies (e.g. Maurer et al. 2006; Pedashenko et al. 2013; Turtureanu et al. 2014) while in others it was physical habitat that had the greatest effect (Löbel et al. 2006; Chytrý et al. 2007; Moeslund et al. 2013; Merunková et al. 2014). One reason for heterogeneous findings may be the existence of interactions among environmental variables (Bakker et al. 2006; Chytrý et al. 2007; de Bello et al. 2007; Huston 2014). A second reason could be that many studies did not cover a sufficiently long gradient of the independent variable, thus missing the peak of humpshaped relationships (Fraser et al. 2015). Further, the patterns of biodiversity-environment relationships may strongly depend on spatial scale (Auestad et al. 2008; de Bello et al. 2007; Turtureanu et al. 2014) or differ between $\alpha$ - and $\beta$-diversity (de Bello et al. 2007; Hanke et al. 2014). Finally, it should be stressed that while non-vascular plants (bryophytes and lichens) often contribute significantly to biodiversity levels of Eurasian dry grasslands (Dengler 2005; Löbel et al. 2006), their diversity-environment relationships are much less well-known and they seem to show contrasting responses to environmental variables compared to vascular plants (see Kuzemko et al. 2016 in this issue, for a brief review). 
The aim of our study thus was to contribute to the general knowledge of plant diversity patterns in natural steppes of the Palaearctic. For this purpose, we selected the Republic of Khakassia in Central Siberia, Russia, which is particularly interesting as a study area because here the two main ecological-geographical types of Palaearctic steppes-the West Palaearctic steppes and the Central Asian steppes-co-occur in the same landscape(Lavrenko et al. 1991). The steppes of Khakassia still cover huge areas and comprise, among others, specific cryo-petrophytic communities (rocky steppes strongly influenced by frost in winter) with a high proportion of glacial relicts (Polyakova and Larionov 2012; Ermakov et al. 2014). The conservation relevance of these communities is also enhanced by the occurrence of a large number of red-list taxa at regional and national scale (Ankipovich et al. 2012). Previous studies on the vegetation of Khakassian steppes were mainly devoted to plant community classification (Kuminova et al. 1976; Makunina 2006; Ermakov 2012), conservation assessment of communities with Red Data Book species (Polyakova 2013) and large-scale mapping (Ermakov et al. 2014). One study addressed diversity-environment relationships of steppe, forest and tundra communities across along bioclimatic and edaphic gradient in a region adjacent to our study area (Chytrý et al. 2007). However this study was restricted to vascular plants and had a fixed plot size of $100 \mathrm{~m}^{2}$.

We sampled vascular plant, bryophyte and lichen composition in nested plots of seven different sizes $\left(0.0001-100 \mathrm{~m}^{2}\right)$ along topographic, edaphic and bioclimatic gradients, using the well-established multi-scale sampling approach of the EDGG Research Expeditions (see Dengler 2009b for a description of the methodology), to answer the following questions:(i) How rich in plant species are the natural steppes of Southern Siberia compared to natural and semi-natural grasslands in other regions of the Palaearctic? (ii) What are the main environmental drivers of the diversity patterns in these steppes? (iii) What are the diversity-environment relationships and do they vary between spatial scales and among different taxonomic groups?

\section{Methods}

\section{Study area}

Our study was conducted in the northern part of the Minusinskaya Basin $\left(54^{\circ}-55^{\circ} \mathrm{N}, 88^{\circ}-\right.$ $90^{\circ} \mathrm{E}$; Fig. 1), located in the Republic of Khakassia, Russia. This intermountain basin extends $180 \mathrm{~km}$ in northeast-southwest direction with a width of $60-100 \mathrm{~km}$ and is situated between the large mountain systems of the Kuznetskij Alatau in the West, Western Sayan in the South and Eastern Sayan in the East. The area has gently undulating landforms and elevation is between 150 and 700 m.a.s.l.

Due to the "rain shadow" effect by the Kuznetskij Alatau, little of the westerly humid air masses reaches the basin, resulting in an ultra continental climate. Winters are extremely cold, while summers are warm (see Table 1 for mean temperatures).Annual precipitation is 300-550 mm (modelled data based on Gidrometeoizdat 1966-1970), with up to $80 \%$ falling between April and October (Gavlina 1954). In winter, snow cover does not exceed $10-20 \mathrm{~cm}$, and is unevenly distributed: wind-exposed slopes are often snow-free, leading to deeply frozen soils. The growing season is short, spanning from late May to mid-September, when there is the onset of frost events (Kuminova et al. 1976).

The soils are characterized by low humus content, but high carbonate content (Nikolskaya 1968; Kuminova et al. 1976). The most common soil types in Khakhassia include 

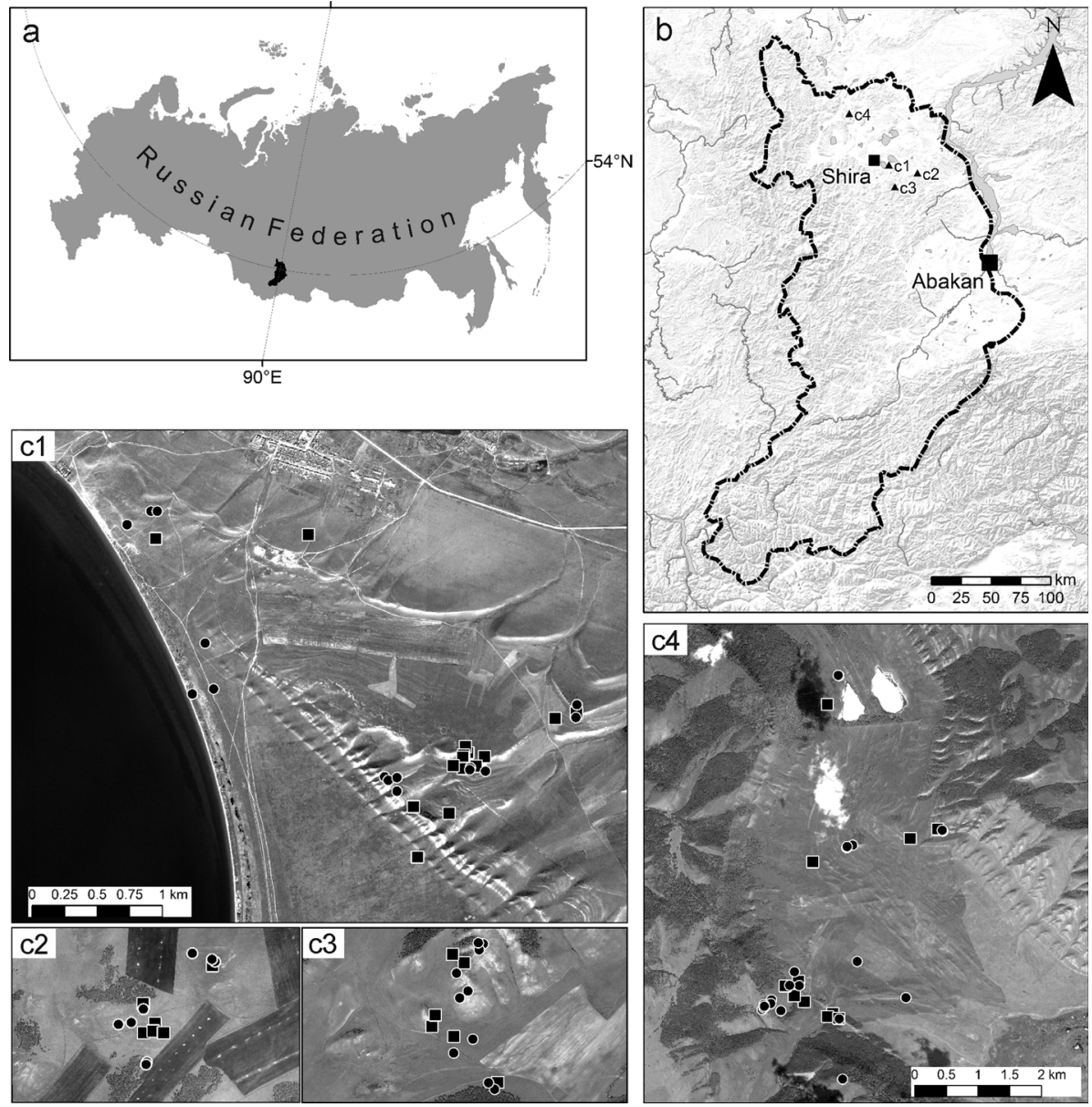

Fig. 1 Location of Khakassia within Russia (a) and of the four sampling sites b within Khakassia: c1 surroundings of Itkul Lake, c2 around the village of Gol'dzha, c3 around the village of Katyushkino, c4 Podzaploty area. Squares indicate all sampled nested-plot series $(n=39)$ and circles additional $10-\mathrm{m}^{2}$ plots $(n=54)$. Images $\mathbf{c 2}$ and $\mathbf{c 3}$ have the same scale as $\mathbf{c 1}$. Background images for $\mathbf{c 1 - c 4}$ obtained from opensource Google Earth

haplic kastanozems chromic and haplic chernozemspachic, below and above 300 m.a.s.l., respectively (Gradoboev 1954; Kolyago 1967).

The natural steppe vegetation occupy $21.7 \%$ of total area of Khakassia and is distributed in the steppe and the forest-steppe belts. The rest of the area is covered by forest (46\%), floodplain and semi-natural meadow (11.5\%), hight-mountain (10.8\%) and other types $(10 \%)$ of vegetation (Kuminova et al. 1976). The various plant communities of Khakassian steppes are traditionally assigned to two different phytosociological classes, the Euro-Siberian steppes of the Festuco-Brometea and the Central Asian steppes of the Cleistogenetea squarrosae (Korolyuk 2002). Cleistogenetea communities are characterized by a predominance of xerophytic Central Asian and Mongolian species, while in Khakassia, Festuco-Brometea communities represent meadow-steppes with prevailing mesophytic Eurasian species. Both classes co-occur in the landscapes of the Minusinskaya 
Table 1 Summary data of all environmental variables used in analyses prior to modelling and those included in the further modelling of species richness of the $10-\mathrm{m}^{2}$ plots $(n=126)$ with an indication of addition of squared terms to modelling and the of data transformation applied to improve normality, if needed

\begin{tabular}{|c|c|c|c|c|c|c|c|}
\hline Environmental parameter & Mean & SD & Min. & Max. & $\begin{array}{l}\text { Inclusion in the } \\
\text { full model }\end{array}$ & $\begin{array}{l}\text { Squared } \\
\text { terms }\end{array}$ & $\begin{array}{l}\text { Data } \\
\text { transformation }\end{array}$ \\
\hline \multicolumn{8}{|l|}{ Topography } \\
\hline Elevation (m.a.s.1.) & 551.4 & 59.4 & 391 & 682 & - & - & - \\
\hline Inclination $\left(^{\circ}\right)$ & 12.0 & 8.8 & 0 & 36 & + & - & Sqrt \\
\hline Heat load index & 0.02 & 0.23 & -0.60 & 0.61 & + & - & - \\
\hline Microrelief $(\mathrm{cm})$ & 6.7 & 7.4 & 0 & 50 & + & - & Sqrt \\
\hline Relief position & \multicolumn{4}{|c|}{$\begin{array}{l}\text { Bottom (39), slope (42), ridge } \\
\text { (45) }\end{array}$} & + & & \\
\hline \multicolumn{8}{|l|}{ Soil } \\
\hline $\mathrm{pH}\left(\mathrm{H}_{2} \mathrm{O}\right)$ & 8.57 & 0.30 & 7.75 & 9.25 & + & - & - \\
\hline $\mathrm{CaCO}_{3}$ content $(\%)$ & 8.10 & 1.84 & 2.5 & 12.5 & - & - & - \\
\hline $\begin{array}{l}\text { Soil skeleton content } \\
(\%)\end{array}$ & 35.2 & 23.8 & 0 & 99 & + & - & Asin of sqrt \\
\hline Humus content $(\%)$ & 8.51 & 3.91 & 1.74 & 17.45 & + & + & - \\
\hline Cover of litter $(\%)$ & 27.0 & 23.0 & 0 & 90 & + & - & Asin of sqrt \\
\hline $\begin{array}{l}\text { Median of soil depth } \\
(\mathrm{cm})\end{array}$ & 25.4 & 18.9 & 0 & 76 & + & - & Sqrt \\
\hline Range of soil depth $(\mathrm{cm})$ & 21.1 & 16.9 & 0 & 90 & + & - & Sqrt \\
\hline \multicolumn{8}{|l|}{ Mesoclimate } \\
\hline $\begin{array}{l}\text { Mean annual } \\
\text { precipitation (mm) }\end{array}$ & 390.4 & 37.7 & 314.0 & 556.6 & + & + & - \\
\hline $\begin{array}{l}\text { Mean annual } \\
\text { temperature }\left({ }^{\circ} \mathrm{C}\right)\end{array}$ & -1.4 & 0.5 & -2.6 & -0.5 & + & - & - \\
\hline $\begin{array}{l}\text { January temperature } \\
\left({ }^{\circ} \mathrm{C}\right)\end{array}$ & -19.2 & 1.0 & -20.6 & -17.5 & - & - & - \\
\hline July temperature $\left({ }^{\circ} \mathrm{C}\right)$ & 16.9 & 0.3 & 15.1 & 17.6 & - & - & - \\
\hline $\begin{array}{l}\text { Evaporation during the } \\
\text { warm period }(\mathrm{mm})\end{array}$ & 340.3 & 9.8 & 318.5 & 352.0 & - & - & - \\
\hline \multicolumn{8}{|l|}{ Land use } \\
\hline Grazing & \multicolumn{4}{|c|}{ Yes (42), no (84) } & + & & \\
\hline
\end{tabular}

Basin, but occupy sites with different ecological and topographical characteristics. Zonal steppes of the Cleistogenetea predominate on flat areas and on the south-facing slopes. The Festuco-Brometea steppes prevail within locally more humid sites on northern slopes.

Khakassian steppes have been used as pastoral land by nomadic tribes since ancient times. The conversion of steppe into arable land began in the early twentieth century (Smelansky and Tishkov 2012), reaching a peak during 1960's. For the last two decades, the proportion of the arable land in the region has decreased as many fields were abandoned during 1990's. Nowadays, steppes, including "petrophytic communities" (i.e. rocky grasslands), occupy $47.5 \%$ of the steppe belt and nearly $50 \%$ of forest-steppe belt of Khakassia (Kuminova et al. 1976). Today grazing and mowing are the main land-use types within the remaining steppe areas (Kandalova and Lysanova 2010). There is no agricultural 
land use within the "Khakassky" nature reserve $\left(2680 \mathrm{~km}^{2}\right)$, in which seven of its nine subunits are located in the steppe and forest steppe zones $\left(273 \mathrm{~km}^{2}\right)$.

\section{Plot selection and arrangement}

Field work took place during the 6th Research Expedition of the European Dry Grassland Group (EDGG; see Vrahnakis et al. 2013) in the second half of July 2013 at the peak development of vegetation. Four main areas were sampled to cover as much as possible of the different habitats of steppe communities (Fig. 1). Within each of these areas we subjectively selected homogenous stands of the different physiognomic and ecological types of steppe vegetation that could be recognized in the field; replicates of the same type were sampled only if clearly separated, to avoid pseudo-replication. We only sampled in the steppe and forest-steppe zones. Our plots were concentrated in protected, unmanaged areas within the nature reserve, but some of them were located in moderately grazed land outside the protection zone.

We sampled 39 nested-plot series ("biodiversity plots") following the basic concept proposed by Dengler (2009b) and implemented in previous EDGG Research Expeditions, such as Romania (Turtureanu et al. 2014), Ukraine (Kuzemko et al. 2016, in this issue) and Bulgaria (Pedashenko et al. 2013). Each biodiversity plot was a square of $100 \mathrm{~m}^{2}$, with square-shaped subplots of $0.0001,0.001,0.01,0.1,1$ and $10 \mathrm{~m}^{2}$ arranged in nested series in two opposite corners. In addition, we sampled 54 quadrats ("normal plots") of $10 \mathrm{~m}^{2}$, resulting in 132 plots at the $10-\mathrm{m}^{2}$ scale for richness data. Due to missing environmental data, one $10-\mathrm{m}^{2}$ plot in one "biodiversity plot" and four "normal plots" were excluded from the analyses of diversity-environment relations. For each nested plot and normal plot, we recorded geographic coordinates and elevation with a GPS device.

\section{Field sampling}

For plots of all sizes we recorded all species of vascular plants, terricolous bryophytes, lichens and macroscopic taxa of 'algae' using the any-part present system (see Dengler 2008), while critical specimens (mainly small cryptogams) were collected for further determination. Nomenclature follows Czerepanov (1995) for vascular plants, Ignatov et al. (2006) for mosses and Andreev et al. (1996) for lichens.

For all $10-\mathrm{m}^{2}$ plots (normal plots + those placed within nested plots) also environmental parameters were recorded: slope aspect, slope inclination, relief position, microrelief, soil depth. We visually estimated percentage cover of litter. Microrelief was measured as the vertical deviation of the surface from an idealized plane across the plot. Soil depth was measured as the maximum depth reached with an iron pin (diameter of $10 \mathrm{~mm}$, length of $80 \mathrm{~cm}$ ) at five random points within the plot. The median and the range of soil depth (the difference of maximum and minimum measurement within plot) were used in the analyses. Soil sample was taken to measure $\mathrm{pH}$ (in water), content of humus, $\mathrm{CaCO}_{3}$ and soil skeleton content $(\%)$ of a mixed sample from five randomly placed sub-samples from the upper $10 \mathrm{~cm}$ layer. We are aware that the microhabitat conditions in plots of sizes other than $10 \mathrm{~m}^{2}$ could differ from the measured values, but we nevertheless use those values to model richness patterns within all sampled spatial scales. We assume that within-plot variation of measured factors is smaller than between-plot variation. Moreover, measuring all microhabitat variables within all spatial grains would not have been feasible. 
The plot data are stored in and available from the Database Species-Area Relationships in Palaearctic Grasslands (EU-00-003; Dengler et al. 2012), registered in the Global Index of Vegetation-Plot Databases (GIVD; Dengler et al. 2011).

\section{Extraction of climatic variables}

Heat load index was calculated for each plot as a proxy of microclimate (especially of dryness), using slope aspect and inclination (Olsson et al. 2009). Mesoclimate did not vary much between our sites despite the geographical distance, thus we used only five basic parameters mean annual temperature, mean annual precipitation, January mean temperature, July mean temperature and evaporation during the warm period, all extracted in ArcGIS 10.2 from a climatic model. The model was obtained by integrating weather data from Russian climate stations (Gidrometeoizdat 1966-1970) with elevation information from a digitized 1:200,000 topographic map. Temperature values were interpolated across the elevation gradient according to the adiabatic lapse rate of $0.65 \mathrm{~K}$ per $100 \mathrm{~m}$ of elevation. Precipitation was computed from precipitation-altitude charts compiled for each of the bioclimatic sectors of the Altai-Sayan region, defined on the basis of their precipitation regime (Polikarpov et al. 1986). Evapotranspiration was calculated by the climatic model on the basis of temperature and air humidity during the growing season. We decided against using the WorldClim precipitation data (Hijmans et al. 2005; http://www. worldclim.org/), because they appeared unrealistic for our study area when compared to local sources.

\section{Analyses of richness-environment relationships}

Before assessing richness-environment relationships, were selected 13 variables out of 18 that did not exhibiting strong collinearity among each other (Pearson linear correlation $|r|<0.7$, Table 1).To test whether data were normally distributed, data on each environmental variable was checked visually using histogram, QQ plot and box plot graphs. If the distribution deviated strongly from normality, an appropriate data transformation was applied (for details see Table 1). One more $10-\mathrm{m}^{2}$ plot was removed from further analyses at the stage of model preparation as it disproportionally influenced model results, as indicated by partial leverage plots (the heat load index value of this plot was an extreme outlier and had both high leverage and high influence in the regression). For two explanatory variables, humus content and mean annual precipitation, squared terms were additionally included in the analyses as those improved model performance in the univariate generalized linear models with Poisson error distribution that we conducted prior to the main analyses $(\triangle \mathrm{AICc}>2$ when comparing model with and without quadratic term, Table 1).

In the main analyses, environmental variables explaining species richness patterns were analysed using a multi model interference based on generalized linear models (GLMs) with Poisson error distribution. We used Akaike information criterion for small sample size (AICc; Burnham and Anderson 2002) as measure of model quality. The estimation of variable importance was based on multimodel inference (Burnham and Anderson 2002) as implemented in the R-package MuMIn version 1.14.; Barton 2015). This approach calculates AICc values for the full model and all partial models derived by any possible combination of 1 to all variables of the full model. The relative importance of each variable 
is then calculated by summing the Akaike weights over all models that contain the specific variable (Johnson and Omland 2004). Importance values range from 0 to 1 , with values close to 1 indicating that a variable is included in all statistically plausible models.

Analyses of richness-environment relationships were finally carried out for data collected within plots of the area $10 \mathrm{~m}^{2}(n=126)$ for overall species richness and separately for different taxonomic groups as vascular plants, non-vascular plants (bryophytes and lichens together) and bryophytes and lichens separately. Moreover, to identify differences in important predictors between spatial scales, nested-plot series (data collected from spatial scales from $0.0001 \mathrm{~m}^{2}$ to $100 \mathrm{~m}^{2}, n=77$ per scale but 39 for $100 \mathrm{~m}^{2}$ ) were analysed for total species richness, vascular and non-vascular plants.

The assumption of equidispersion was evaluated using function dispersion test R-package AER version 1.2-4 tests (Kleiber and Zeileis 2008). As significant overdispersion was found particularly for overall species richness, all analyses were repeated using negative binomial generalized linear models. Results did not differ qualitatively from those of the GLMs (Online Resource 1). No significant spatial autocorrelation was detected in the residuals of any model when tested using function moran.test in R-package spdep version 0.5-88 (Bivand and Piras 2015). McFadden's pseudo- $R^{2}(1-(\log$ likelihood of the full model/log likelihood of the null model)) was calculated for the "best" (in terms of AICc) GLMs in order to compare the amount of variability explained by the response variables between different scales. Note that McFadden's pseudo- $R^{2}$ tends to report much smaller values when compared to common $R^{2}$ measures (see Online Resource 2 for demonstration of similarity in patterns of different $R^{2}$ measures).

\section{Analyses of species-area relationships and $\beta$-diversity}

We used the "slopes" of the species-area relationships (SARs), to quantify $\beta$-diversity (Riccota et al. 2002; Jurasinski et al. 2009). Specifically, we used the so-called $z$-values, one of the parameters of power-law SARs. The power law $\left(S=c A^{z}\right.$, with $S=$ species richness, $A=$ area, $c$ and $z$ being fitted parameters) has been shown to be to a good general approximation for the increase of species richness with area at any spatial scale (Connor and McCoy 1979; Dengler 2009a), and the $z$-value is widely used to compare spatial species turnover between different ecological situations (Drakare et al. 2006; de Bello et al. 2007). The $z$-values can be seen as the logarithmic transformation of multiplicative $\beta$ diversity $\left(\beta_{\text {mult }}=S_{\gamma} / S_{\alpha}\right.$, where $S_{\gamma}$ and $S_{\alpha}$ are the mean species richness values at the coarse and at the fine grain sizes, respectively; Jurasinski et al. 2009), standardised by the increase in grain size between the $\alpha$ - and $\gamma$-level, i.e.:

$$
z=\log _{10}\left(\frac{S_{\gamma}}{S_{\alpha}}\right) / \log _{10}\left(\frac{A_{\gamma}}{A_{\alpha}}\right)
$$

We calculated the $z$-values in double-log space, i.e. $\log _{10} S=\log _{10} c+\mathrm{z} \log _{10} A$ with linear regression (Drakare et al. 2006; Dengler 2009a), resulting in an overall $z$-value. Second, we calculated "local" $z$-values between two subsequent plot sizes to test whether $\beta$-diversity depends on spatial scale, i.e. the actual relationship deviates from a perfect power law (Turtureanu et al. 2014; see also de Bello et al. 2007). Both calculations were performed separately for each of the 39 biodiversity plots, using for each grain size the mean richness values of the two corners. 


\section{Results}

\section{Species richness at different spatial scales}

In the whole dataset, we identified 498 taxa: 352 vascular plants (71\%), 75 bryophytes (15\%), 69 lichens (14\%) and two macroscopic taxa of terricolous "algae". Among vascular plants, the most frequent graminoid species were Stipa krylovii, Helictotrichon schellianum and Carex humilis, and the most frequent forbs were Thalictrum foetidum, Aster alpinus, Bupleurum scorzonerifolium, Galium verum, Hedysarum gmelinii and Schizonepeta multifida (Online Resource 3). Regarding non-vascular plants, the most frequent species were Cladonia pyxidata, Peltulaeuploca, Barbula unguiculata, Bryum caespiticium and Weissia condensa.

Mean total species richness varied between 2.3 species at the smallest spatial scale $\left(0.0001 \mathrm{~m}^{2}\right)$ and 73.4 species at $100 \mathrm{~m}^{2}$ scale (Table 2). Species richness of vascular plants was evenly distributed among the plots, in contrast to non-vascular plants, for which the standard deviation of species richness exceeded the mean up to a plot size of $0.1 \mathrm{~m}^{2}$. The maximum recorded species richness for all taxonomic groups was 5 species in $0.001 \mathrm{~m}^{2}, 80$ species in $10 \mathrm{~m}^{2}$, and 106 species on $100 \mathrm{~m}^{2}$ plots (for vascular plants the numbers are 5 , 72 and 94, and for non-vascular plants 3, 22 and 26, respectively) (Table 2). At the plot scale, the average proportion of vascular plants was higher and varied between $84 \%$ (in the $0.01-\mathrm{m}^{2}$ plots) and $92 \%$ (in the $0.0001-\mathrm{m}^{2}$ plots). The species richness of non-vascular plants was lower than that of vascular plants at all spatial scales. The species richness of bryophytes exceeded that of lichens only at smaller spatial scales (Table 2).

\section{Taxon-dependence of species richness-environment relationships}

Species richness in the $10-\mathrm{m}^{2}$ plots $(n=126)$ was controlled predominantly by heat load index (negative linear relationship), mean annual precipitation (hump-shaped relationship) humus content (hump-shaped relationship) and soil skeleton content (positive linear relationship) (Fig. 2a; Table 3).

Vascular plant richness followed the same patterns as total richness with respect to humus content, mean annual precipitation, heat load index and soil skeleton content. However, vascular plant species richness was also affected by relief (higher species richness at the 'bottom' than on 'slopes' and 'ridges') and was positively correlated with cover of litter, $\mathrm{pH}$ and range of soil depth (Fig. 2b; Table 3).

Species richness of bryophytes, similar to total richness and vascular plants, was also affected by heat load index (negatively) and relief (but with higher species richness on 'slopes' and 'ridges' than at the 'bottoms' of valleys). On the other hand it was positively associated with mean annual precipitation and mean annual temperature. The relationship of bryophyte species richness with humus content was hump-shaped (Fig. 2c; Table 3).

Species richness of lichens was strongly negatively associated with soil depth, cover of litter, microrelief, and humus content. Similarly to bryophytes, lichens species richness was higher on ridges than in valley bottoms. Their relationship with mean annual precipitation was hump-shaped, with the maximum richness at mean precipitation values (around $450 \mathrm{~mm}$ ) (Fig. 2d; Table 3). 


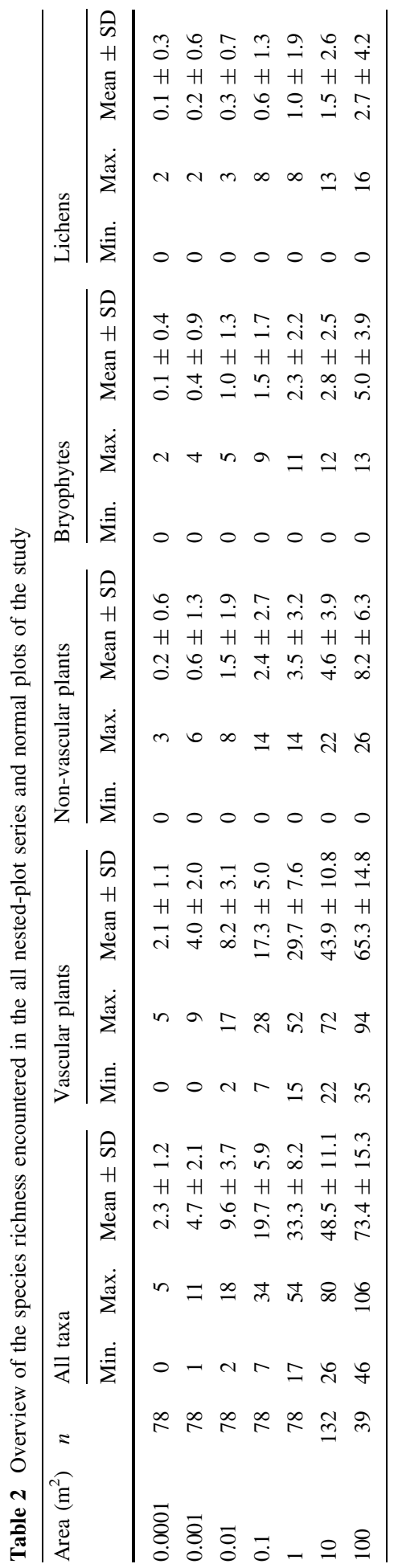


a Total richness

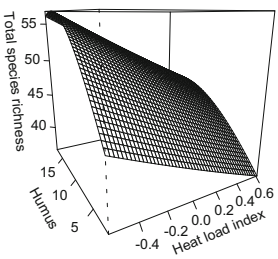

C Bryophytes

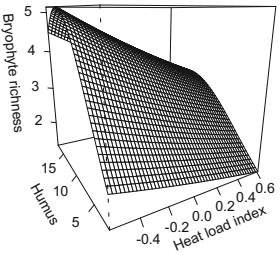

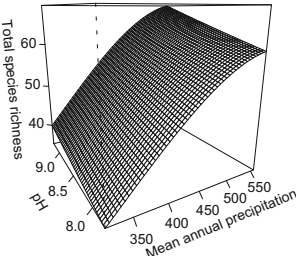

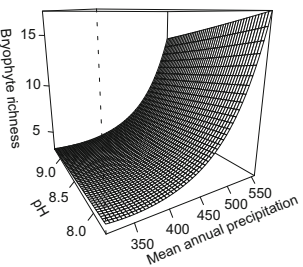

b Vascular plants

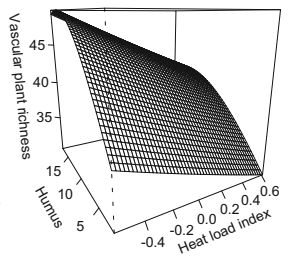

d Lichens

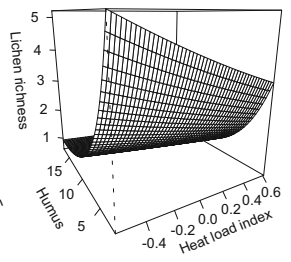

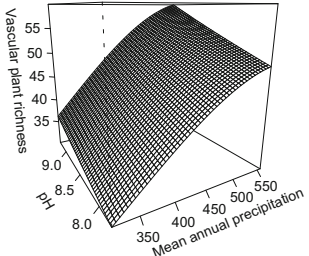

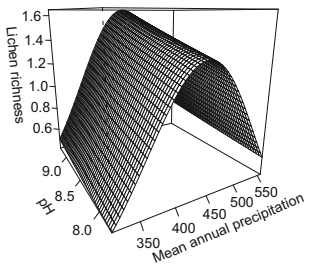

Fig. 2 Effect of heat load index, humus, $\mathrm{pH}$ and mean annual precipitation on a total richness, $\mathbf{b}$ vascular plant, $\mathbf{c}$ bryophyte and $\mathbf{d}$ lichen richness within $10-\mathrm{m}^{2}$ plots $(n=126)$. Response surfaces were calculated based on full models (GLM with Poisson family error) using function visreg2d in R package visreg version 2.2-0 (Breheny and Burchett 2015)

Table 3 Estimates of the relative importance of predictor variables in the multiple regression models of total, vascular, non-vascular, bryophyte and lichen species richness within $10-\mathrm{m}^{2}$ plots $(n=126)$ assessed with multimodel inference

All species Vascular plants Non-vascular plants Bryophytes Lichens

\begin{tabular}{|c|c|c|c|c|c|}
\hline \multicolumn{6}{|l|}{ Topography } \\
\hline Inclination & $0.26^{-}$ & $0.26^{-}$ & $0.26^{+}$ & $0.25^{-}$ & $0.33^{-}$ \\
\hline Heat load index & $0.94^{-}$ & $0.82^{-}$ & $0.59^{-}$ & $0.64^{-}$ & $0.27^{-}$ \\
\hline Microrelief & $0.31^{+}$ & $0.51^{+}$ & $0.65^{-}$ & $0.28^{-}$ & $0.66^{-}$ \\
\hline Relief position & 0.13 & 0.91 & 1.00 & 1.00 & 1.00 \\
\hline Ridge versus bottom & - & - & + & + & + \\
\hline Slope versus bottom & - & - & + & + & + \\
\hline \multicolumn{6}{|l|}{ Soil } \\
\hline $\mathrm{pH}$ & $0.47^{+}$ & $0.77^{+}$ & $0.27^{-}$ & $0.33^{-}$ & $0.33^{+}$ \\
\hline Soil skeleton content & $0.57^{+}$ & $0.52^{+}$ & $0.26^{+}$ & $0.25^{+}$ & $0.29^{-}$ \\
\hline Humus content & $0.88^{+}$ & $0.92^{+}$ & $0.28^{+}$ & $0.76^{+}$ & $0.82^{-}$ \\
\hline Humus content ${ }^{2}$ & $0.62^{-}$ & $0.68^{-}$ & $0.31^{-}$ & $0.57^{-}$ & $0.47^{+}$ \\
\hline Cover of litter & $0.48^{+}$ & $0.91^{+}$ & $0.96^{-}$ & $0.29^{-}$ & $0.96^{-}$ \\
\hline Median of soil depth & $0.27^{-}$ & $0.33^{+}$ & $0.97^{-}$ & $0.31^{+}$ & $1.00^{-}$ \\
\hline Range of soil depth & $0.49^{+}$ & $0.57^{+}$ & $0.24^{+}$ & $0.42^{+}$ & $0.28^{-}$ \\
\hline \multicolumn{6}{|l|}{ Mesoclimate } \\
\hline Mean annual precipitation & $0.91^{+}$ & $\mathbf{0 . 8 3}^{+}$ & $0.65^{+}$ & $0.57^{-}$ & $0.49^{+}$ \\
\hline Mean annual precipitation ${ }^{2}$ & $0.73^{-}$ & $0.63^{-}$ & $0.53^{-}$ & $0.68^{+}$ & $0.46^{-}$ \\
\hline Mean annual temperature & $0.27^{-}$ & $0.30^{-}$ & $0.97^{+}$ & $0.99^{+}$ & $0.45^{-}$ \\
\hline
\end{tabular}


Table 3 continued

All species $\quad$ Vascular plants Non-vascular plants Bryophytes Lichens

Land use

$\begin{array}{llllll}\text { Grazing: yes versus no } & 0.46^{+} & 0.46^{+} & 0.25^{+} & 0.47^{+} & 0.24^{-}\end{array}$

Values higher than 0.5 are set in bold. Positive and negative signs after the values indicate positive or negative relations of species richness to the focal variable; unimodal relationships exist when there is a negative quadratic term of the same variable, while a positive quadratic term indicates u-shaped relationship

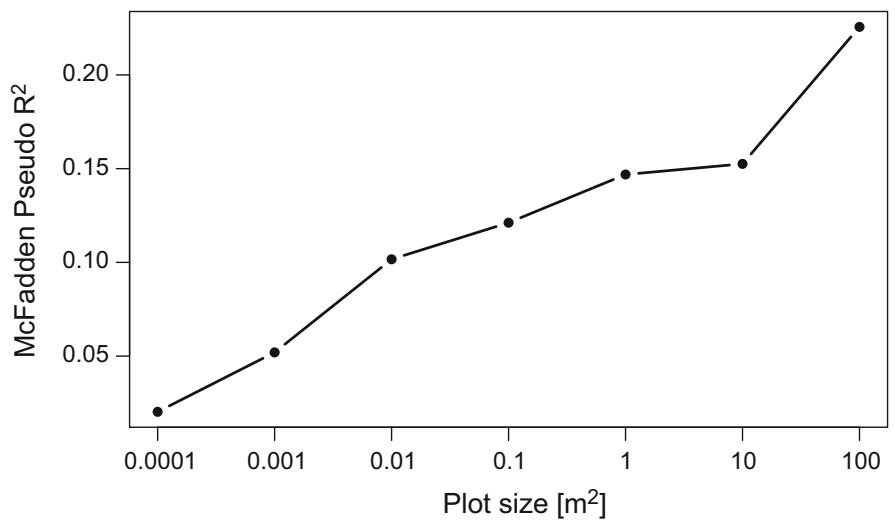

Fig. 3 Change of the explanatory power of the regression model for total species richness across the studied spatial scales from 0.0001 to $100 \mathrm{~m}^{2}\left(n=77\right.$ for $0.0001-10 \mathrm{~m}^{2} ; n=39$ for $100 \mathrm{~m}^{2}$ and $z$-values). Note that McFadden's pseudo- $R^{2}$ is not comparable to common $R^{2}$ measures as it tends to be small

\section{Scale-dependence of richness-environment relationships}

The explanatory power of the regression models for the 77 series of nested plots was highest at a plot size of $100 \mathrm{~m}^{2}$, with a secondary peak for $10-\mathrm{m}^{2}$ plots, gradually decreasing towards the smallest scales (Fig. 3).

Heat load index was the most important factor (with a negative correlation), for total species richness across most of the spatial scales with a particularly high significance for $0.01,1$, and $10 \mathrm{~m}^{2}$ (Table 4, Online Resource 4). Microrelief was important at scales from 0.01 to $0.1 \mathrm{~m}^{2}$ (with a negative correlation), while soil skeleton content had an increasingly positive effect with increasing plot size, and became very important at scales from 10 to $100 \mathrm{~m}^{2}$. Relief was most important at the scale of $0.1 \mathrm{~m}^{2}$, and was of negligible importance for the total richness at the largest and smallest spatial scales. As for climatic variables, annual precipitation was important at most spatial scales. It exhibited a hump-shaped relationship with total species richness at small scales and a strongly positive relationship at scales from 10 to $100 \mathrm{~m}^{2}$. Mean annual temperature was (moderately) important only at the scale of $1 \mathrm{~m}^{2}$. Presence of grazing had a positive influence on total species richness only at the scale of $0.1 \mathrm{~m}^{2}$ (Table 4, Online Resource 4).

\section{Species-area relationships and $\beta$-diversity}

The overall $z$-values for all taxonomic groups and across all plot sizes ranged from 0.197 to 0.345 , with a mean of 0.258 in the 39 nested-plot series. Among the studied factors, the 
Table 4 Estimates of relative parameter importance for the seven spatial scales of $\alpha$-diversity and of the overall $z$-value as measure of $\beta$-diversity based on multimodel inference $\left(n=77\right.$ for $0.0001-10 \mathrm{~m}^{2} ; n=39$ for $100 \mathrm{~m}^{2}$ and overall $z$-values)

\begin{tabular}{|c|c|c|c|c|c|c|c|c|}
\hline & $0.0001 \mathrm{~m}^{2}$ & $0.001 \mathrm{~m}^{2}$ & $0.01 \mathrm{~m}^{2}$ & $0.1 \mathrm{~m}^{2}$ & $1 \mathrm{~m}^{2}$ & $10 \mathrm{~m}^{2}$ & $100 \mathrm{~m}^{2}$ & $z$ \\
\hline \multicolumn{9}{|l|}{ Topography } \\
\hline Inclination & $0.28^{-}$ & $0.24^{-}$ & $0.24^{-}$ & $0.30^{+}$ & $0.41^{-}$ & $0.26^{-}$ & $0.23^{-}$ & $0.24^{+}$ \\
\hline Heat load index & $0.45^{-}$ & $0.61^{-}$ & $0.92^{-}$ & $0.45^{-}$ & $0.97^{-}$ & $0.85^{-}$ & $0.44^{-}$ & $0.38^{+}$ \\
\hline Microrelief & $0.24^{+}$ & $0.31^{-}$ & $0.80^{-}$ & $0.71^{-}$ & $0.25^{-}$ & $0.51^{+}$ & $0.24^{+}$ & $0.71^{+}$ \\
\hline Relief position & 0.15 & 0.13 & 0.49 & 0.98 & 0.65 & 0.15 & 0.08 & 0.21 \\
\hline Ridge versus bottom & + & + & + & + & - & - & + & - \\
\hline Slope versus bottom & + & + & - & - & - & - & + & - \\
\hline \multicolumn{9}{|l|}{ Soil } \\
\hline $\mathrm{pH}$ & $0.25^{-}$ & $0.31^{-}$ & $0.40^{-}$ & $0.26^{-}$ & $0.25^{-}$ & $0.24^{+}$ & $0.19^{-}$ & $0.32^{+}$ \\
\hline Soil skeleton content & $0.24^{+}$ & $0.33^{+}$ & $0.53^{+}$ & $0.47^{+}$ & $0.67^{+}$ & $0.93^{+}$ & $0.88^{+}$ & $0.21^{+}$ \\
\hline Humus content & $0.29+$ & $0.44^{+}$ & $0.38^{+}$ & $0.59^{+}$ & $\mathbf{0 . 5 0} 0^{+}$ & $0.59^{+}$ & $0.50^{+}$ & $0.21^{+}$ \\
\hline Humus content $^{2}$ & $0.31^{+}$ & $0.40^{+}$ & $0.33^{+}$ & $0.46^{+}$ & $0.48^{+}$ & $0.46^{+}$ & $0.57^{+}$ & $0.20^{+}$ \\
\hline Cover of litter & $0.45^{+}$ & $0.36^{+}$ & $0.24^{+}$ & $0.26^{-}$ & $0.40^{+}$ & $0.61^{+}$ & $0.20^{-}$ & $0.26^{-}$ \\
\hline Median of soil depth & $0.31^{+}$ & $0.30^{+}$ & $0.25^{+}$ & $0.28^{+}$ & $0.26^{-}$ & $0.26^{+}$ & $0.20^{+}$ & $0.24^{+}$ \\
\hline Range of soil depth & $0.34^{+}$ & $0.24^{-}$ & $0.23^{-}$ & $0.24^{+}$ & $0.24^{-}$ & $0.23^{+}$ & $0.80^{+}$ & $0.20^{+}$ \\
\hline \multicolumn{9}{|l|}{ Mesoclimate } \\
\hline $\begin{array}{l}\text { Mean annual } \\
\text { precipitation }\end{array}$ & $0.29^{+}$ & $0.55^{+}$ & $0.75^{+}$ & $0.60^{+}$ & $0.64^{+}$ & $0.60^{+}$ & $0.55^{+}$ & $0.73^{-}$ \\
\hline $\begin{array}{l}\text { Mean annual } \\
\text { precipitation }^{2}\end{array}$ & $0.29^{-}$ & $0.52^{-}$ & $0.71^{-}$ & $0.55^{-}$ & $0.57^{-}$ & $0.55^{+}$ & $0.55^{+}$ & $0.73^{+}$ \\
\hline $\begin{array}{l}\text { Mean annual } \\
\text { temperature }\end{array}$ & $0.26^{+}$ & $0.29^{+}$ & $0.27^{+}$ & $0.25^{-}$ & $0.56^{-}$ & $0.29^{-}$ & $0.25^{+}$ & $0.42^{-}$ \\
\hline \multicolumn{9}{|l|}{ Land use } \\
\hline Grazing: yes versus no & $0.24^{+}$ & $0.37^{-}$ & $0.24^{+}$ & $0.54^{+}$ & $0.29^{+}$ & $0.24^{+}$ & $0.18^{-}$ & $0.21^{+}$ \\
\hline
\end{tabular}

Values higher than 0.5 are set in bold. Positive and negative signs after the values indicate positive or negative relations of species richness to the focal variable; unimodal relationships exist when there is a negative quadratic term of the same variable, while a positive quadratic term indicates u-shaped relationship

overall z-values were positively related to microrelief had a u-shaped relationship with differences in mean annual precipitation (Table 4). The local $z$-values were significantly scale-dependent (repeated measures ANOVA: $p<0.001$ ). The highest mean $z$-values were found at the smallest spatial scales (with a maximum of 0.322 at the $0.01-0.1 \mathrm{~m}^{2}$ transition) and gradually decreased above these plot sizes (reaching only 0.166 for the transition $10-100 \mathrm{~m}^{2}$ ) (Fig. 4). Maximum variance in the local $z$-values was found at the smallest plot sizes, where also the highest absolute $z$-values were recorded (Fig. 4).

\section{Discussion}

\section{Diversity of Khakassian steppes in comparison with other regions}

In general, our mean and maximum species richness values were in the range found in other Palaearctic dry grasslands (reviewed by Kuzemko et al. 2016 in this issue). At all spatial scales between 0.01 and $100 \mathrm{~m}^{2}$, our maximum as well as mean vascular plant 


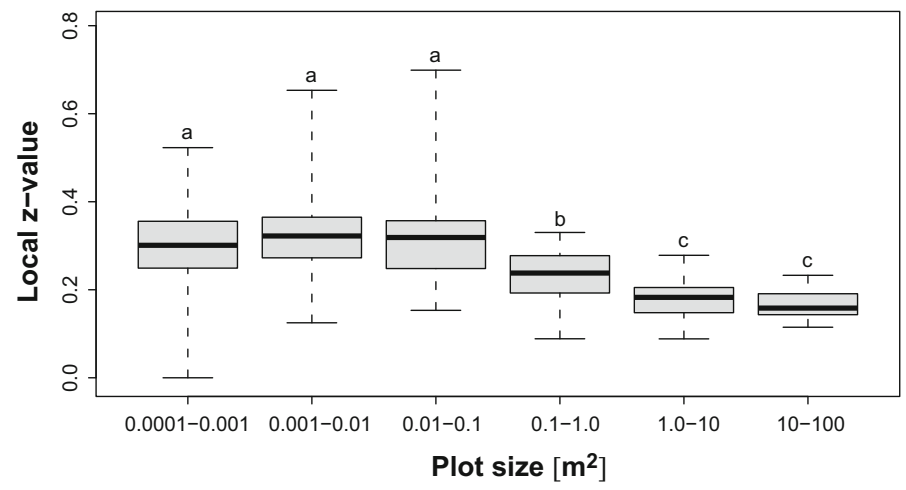

Fig. 4 Changes of species turnover or $\beta$-diversity (expressed asz-values) with spatial scale in the 39 biodiversity plots. Box plots of local z-values for each pair of subsequent plot sizes are shown. Letters indicate homogenous groups according to Tukey's post hoc test. Medians and interquartile ranges (IQR) are shown by boxes; whiskers indicate ranges from Q1 - 1.5(IQR) to Q3 + 1.5(IQR)

species richness were higher than those of semi-natural dry grasslands of Europe, with the exception of those in Transylvania (Turtureanu et al. 2014). Compared to other natural Palaearctic steppes, those in Khakassia were much richer at $100 \mathrm{~m}^{2}$ than those of the Russian province of Tyuman (27 species reported by Mathar et al. 2016, this issue).

Unlike dry grasslands in Central Podolia (Kuzemko et al. 2016 in this issue) nonvascular plants were present at all scales. Non-vascular plants were generally most frequent and abundant in sites where abundance of vascular plants was limited by environmental stress, especially in the petrophytic steppe, which is in accordance with other studies demonstrating the competitive superiority of vascular over the non-vascular plants (Wal et al. 2005).

\section{Richness-environment relationships}

In our dataset, the environmental variable most markedly controlling species richness of vascular plants (and, less strongly, of non-vascular plants, especially lichens) was heat load index, with a negative correlation. This is very similar to the findings by Kuzemko et al. (2016, in this issue) for the Podolian steppes in Ukraine and by Turtureanu et al. (2014) for Transylvanian semi-natural grasslands. For Podolia, this finding was explained in that south-facing, steep slopes in a summer-warm climate give rise to a habitat with a marked drought stress that prevents colonization by many species of the regional species pool (Kuzemko et al. 2016, in this issue). In the extreme continental climate of Khakassia, the causal mechanism for the negative correlation between richness and heat load could also take place in spring, when solar radiation on south-facing slopes is already high but temperatures are still low and the soil is still frozen, leading to strong physiological drought (see Jarvis and Linder 2000).

Vascular plant richness had also a very strong negative correlation with convex topographic positions: diversity was much higher in bottoms than on ridges. Contrary to a positive correlation with convex topographic position found in Danish grassland diversity (Moeslund et al. 2013), our results can be explained again with the ultra continental climate of the study area, characterized by very low winter temperatures and a very little amount of snowfall. During the winter, the wind can blow the snow cover from ridges, 
leaving the soil and vegetation exposed to a long period of severe frost (about five months), with the formation of a layer of frozen ground (up to $2.5 \mathrm{~m}$ deep) with distinct cryogenic processes. This leads to patches of cryo-petrophytic steppe poorer in vascular plants and richer in bryophytes and lichens. In contrast, the presence of even a shallow snow layer in valley bottoms and concave micro-topographic position is favourable for the formation of moderately thermophilous steppes rich in forbs (Ermakov et al. 2014). Moreover, ridges are strongly exposed to erosion, resulting in shallow and nutrient-poor soil leading to unfavourable habitats for many vascular plants, while soil will accumulate in depressions.

The relationship between humus content and vascular plant richness was hump-shaped with the highest richness shifted towards high humus content. This finding might be connected with the productivity-richness relationship, as the humus content is a proxy of soil fertility, and of soil water retention, and thus aboveground productivity. The humpshaped relationship between productivity and vascular plant species richness has recently been confirmed by Fraser et al. (2015). Given the relatively low productivity of the Russian steppes on a global scale (Titlyanova 1991), we can assume that most of our samples were still below the tipping-point of the hump-shaped response that can be found over a large productivity gradient (Fraser et al. 2015). They were thus below levels where competition for light starts to limit vascular plant richness (see Grime 2002; see also Mathar et al. 2016, in this issue), except on the most humus-rich soils (see Fig. 2). The above-mentioned explanations linking diversity patterns of vascular plants within Khakassian dry grasslands with productivity-diversity relationship are additionally supported by the observed strong positive relationship of litter cover with vascular plants species richness, as production of litter is a direct effect of primary productivity (Fraser et al. 2015).

Interestingly, soil $\mathrm{pH}$ had a strong positive effect on vascular plants species richness. The positive effect of the $\mathrm{pH}$ on vascular plants species richness is also remarkable (and currently unexplained) because $\mathrm{pH}$ was, in general, very high (mean 8.57, max. 9.25). The richness-pH relationship has to be inherently unimodal (Chytrý et al. 2007), and for such high $\mathrm{pH}$ values, other studies found that vascular plants richness decreased with increasing pH, in European secondary grasslands (e.g. Becker and Brändel 2007), in South Siberian steppes (Chytrý et al. 2007) and in West Siberian meadows and steppes (Mathar et al. 2016, in this issue).

Among the considered mesoclimatic factors, the only one that was important for most of the studied groups was mean annual precipitation, contrary to other studies that underlined the role of annual temperature (e.g. Palpurina et al. 2015), this can probably be explained because the temperature gradient within our study area was very short. The strong humpshaped relationship of total richness (and that of vascular plants) with precipitation can stem from the same principle as the relationship with humus content. The primary productivity of temperate dry grasslands can be controlled by water to the same extent as nutrient deficiency (Knapp et al. 2001). At high precipitation values, the most competitive and large-sized species (suppressed elsewhere by drought stress), can take dominance, limiting plot richness. As within Khakassian grasslands, the flattening of the precipitationvascular plant species richness curve happened only at the highest values of precipitation: over most of the gradient, the present results can be compared with those of Adler and Levine (2007) or Chytrý et al. (2007) (for steppe vegetation), who described positive relationship of mean annual precipitation with plant species richness. 


\section{Scale-dependence of richness-environment relationships}

Heat load index was more important at medium to large plot sizes, which is in accordance with the results of Turtureanu et al. (2014) from Transylvania and Kuzemko et al. (2016, in this issue) from Ukraine. Humus content was the most important factor between 0.0001 to $0.1 \mathrm{~m}^{2}$ plot sizes in Transylvania, and between 0.1 and $1 \mathrm{~m}^{2}$ in Ukraine; in Khakassia, this predictor variable was most important between 0.1 and $100 \mathrm{~m}^{2}$. These results may contrast with the explanation given by Turtureanu et al. (2014) that resource availability is most important at small spatial scales (see Siefert et al. 2012).

An important positive role of microrelief in the richness model was noted in Transylvania between $0.1-100 \mathrm{~m}^{2}$, which turned negative only for the smallest plot size, consistently with heterogeneity-diversity theory (Tamme et al. 2010). By contrast, in the Khakassian steppes, the influence of microrelief was weakly positive at the smallest scales and strongly negative at plot scales $0.01-1 \mathrm{~m}^{2}$, becoming positive only above $10 \mathrm{~m}^{2}$ (Table 4, Online Resource 4).

Another interesting feature of our results is the strong importance of mean annual precipitation for all plots larger than $0.0001 \mathrm{~m}^{2}$ (Table 4, Online Resource 4). By contrast, both Kuzemko et al. (2016, in this issue) and Turtureanu et al. (2014) found mesoclimatic factors important only at larger spatial scales and gaining importance with scale, which is in accordance with results of meta-analytical studies by Siefert et al. (2012) and Field et al. (2009). The contrasting results of our study can be attributed to the harsh climatic conditions of the study area, where drought and associated lack of snow cover during winter are important stress factors (see Chytrý et al. 2007), which can act at different spatial scales (for example through cryogenic processes).

It is interesting to note that disturbance (grazing, mowing) was found in similar studies as an important predictor variable (Löbel et al. 2006; Turtureanu et al. 2014; Kuzemko et al. 2016, in this issue) positively influencing species richness at different spatial scales. For instance, in Transylvania it had a strong positive effect across all plot sizes between 0.1 and $100 \mathrm{~m}^{2}$, but in the Khakassian dataset it was important for total species richness only at $0.1 \mathrm{~m}^{2}$. At the $10-\mathrm{m}^{2}$ scale its influence was rather weak, but still positive, for all taxonomic groups except lichens. The influence of grazing on grassland species richness strongly depends on its intensity (Dupré and Diekmann 2001). Within the area sampled in the present study, pastoral management was very low intensity (with free-ranging cows). Such type of management can resemble grazing by the wild animals that shaped the steppes of Khakassia from their very beginnings (Akhmetyev et al. 2005). On the other hand, as steppe is the zonal vegetation type within Khakassian lowlands the lack of human management does not result in rapid successional changes and loss of biodiversity, as is the case in semi-natural grasslands of Western and Central Europe (Pykälä et al. 2005). Additionally, as management influence was not the focal question of our study, preferential plot selection avoiding intensively grazed areas shortened the gradient of land use intensity, which could reduce its importance as a factor influencing species richness.

\section{Species-area relationships and $\beta$-diversity}

The z-values as measure of $\beta$-diversity were higher in Khakassia than those found in a review of European dry grassland associations (Dengler 2005) or in Podolian steppes (Kuzemko et al. 2016, in this issue), and nearly as high as in Transylvanian dry grasslands (Turtureanu et al. 2014). The scattered knowledge about z-values in different grassland ecosystem currently hinders an explanation of this outstanding position. In contrast to 
Estonian dry grasslands(Dengler and Boch 2008) and Ukrainian steppes (Kuzemko et al. 2016 in this issue), we found a significant scale-dependency of the local $z$-values, with a shape of the relationship (Fig. 4) similar to that reported by Turtureanu et al. (2014) for Transylvania. We observed an already high value at the smallest transition $\left(0.0001-0.001 \mathrm{~m}^{2}\right)$, gradually increasing up to the maximum at the $0.01-0.1 \mathrm{~m}^{2}$ transition (this is the same spatial scale showing the maximum $z$-value in Transylvania).At larger spatial scales, the mean z-values showed a steep decrease, reaching 0.166 for the transition $10-100 \mathrm{~m}^{2}$ (strikingly similar to the 0.165 value found in Transylvania for the same transition).

As expected, the environmental variable that had a significant positive influence on overall $z$-values was microrelief. This can be viewed as a proxy of micro-ecological heterogeneity within the larger-scale plots (although it was measured only within the $10-\mathrm{m}^{2}$ plot),i.e. of the probability that new, different microhabitats will be included in sampling with increasing plot size, leading to the inclusion of plant species linked to those microsites.

\section{Differences in diversity patterns between vascular plants and non-vascular plants}

Consistent with previous studies (see Turtureanu et al. 2014, and references therein), we found that the richness patterns and drivers of bryophytes and lichens were different than those of vascular plants. For instance, lichen species richness was negatively affected by litter cover and humus content, while vascular plants species richness was generally positively correlated with these factors. Both bryophytes and lichens were more diverse on ridges, while vascular plants were more diverse in valley bottoms. These patterns can be explained by the lack of snow-cover on ridges, exposing the soil to extremely cold temperatures in winter and to drought stress in spring, thus favouring non-vascular plants. The latter instead outcompete bryophytes and lichens on the snow-covered, deep and humusrich soils of the valley bottoms.

We found that soil $\mathrm{pH}$ had a strong positive correlation with vascular plant richness but, contrary to some previous studies (e.g. Löbel et al. 2006), only very weak relationship with non-vascular plant diversity. However, this latter result is similar to the findings of Turtureanu et al. (2014) in Transylvanian secondary grasslands. That phenomenon can be explained by a relatively short $\mathrm{pH}$ gradient, where all sampled sites could be regarded as calcium rich, as is the case in the Transylvanian grasslands (Turtureanu et al. 2014).

Bryophytes were the only group for which species richness was strongly correlated with mean annual temperature (positively) and at the same time strongly positively influenced by mean annual precipitation. As bryophytes are not rooted and thus susceptible to desiccation, their positive relationship with annual precipitation is understandable (see Pharo et al. 2005; Turtureanu et al. 2014). Low winter temperatures have also been found to indirectly negatively influence bryophyte richness through low vapour pressure (Pharo et al. 2005).

\section{Conclusions}

In comparison to other Palaearctic grasslands studied with a comparable methodology, Khakassian steppes ranked quite highly for both $\alpha$-diversity (measured by the mean and maximum richness at each plot size) and $\beta$-diversity (measured as the overall and local $z$ - 
values). We also found a clear peak of local $\mathrm{z}$-values between 0.001 and $0.1 \mathrm{~m}^{2}$, which is currently unexplained.

Consistent with theory and previous studies, the importance of different factors in the regression models explaining richness varied systematically with spatial grain. Moreover, the analysed drivers varied in their importance and sometimes even had contrasting effects on vascular versus non-vascular plants, and partly also between bryophytes and lichens. This indicates the importance of considering groups other than just vascular plants, especially in fundamental ecological studies. Our research confirmed that the steppes of Southern Siberia are, at small spatial scales, one of the plant biodiversity hotspots of the Palearctic, which strengthens the need for the conservation of natural ecosystems in this region.

Acknowledgments The study was jointly planned by J.D. (methodology) with N.E. and M.A.P. (site selection and field work). All authors except M.J.S. were involved in the field sampling, while M.J.S., I.D., R.J. and J.D. carried out the statistical analyses and G.F., E.K. and I.D. created the maps. The text was drafted by M.A.P., I.D., G.F., Ł.K. and J.D. with all authors contributing to its revision. We are grateful to the administration of the "Khakassky" nature reserve for allowing this research and supporting it logistically. We thank Dieter Frank who contributed much to the field sampling of plants and to Svetlana Lebedeva for the excellent food supply under field camp conditions in Podzaploty. We thank Olga Zyryanova for determination of critical lichens, Mikhail S. Ignatov for that of critical bryophytes, Olga Bezuglova for conducting the soils analyses, Alexey Larionov for extracting the climatic variables from the regional model and Carlo M. Rossi for helping with the maps. Many thanks to Didem Ambarlı as Co-ordinating Editor and three anonymous reviewers, whose thoughtful comments on earlier versions of this manuscript contributed much to its improvement, and to Laura Sutcliffe for polishing our English language usage on behalf of the Eurasian Dry Grassland Group (EDGG; http://www.edgg.org). BAYHOST (http://www.uni-regensburg.de/ bayhost) made the research stays of M.A.P. and I.D. in Bayreuth possible through grants to J.D., during which the analyses were conducted and the paper drafted. This study was supported by Russian Scientific Foundation (Grant No. 14-14-00453).

Open Access This article is distributed under the terms of the Creative Commons Attribution 4.0 International License (http://creativecommons.org/licenses/by/4.0/), which permits unrestricted use, distribution, and reproduction in any medium, provided you give appropriate credit to the original author(s) and the source, provide a link to the Creative Commons license, and indicate if changes were made.

\section{References}

Adler PB, Levine JM (2007) Contrasting relationships between precipitation and species richness in space and time. Oikos 116:221-232. doi:10.1111/j.2006.0030-1299.15327.x

Akhmetyev MA, Dodoniv AE, Somikova MV, Spasskaya II, Kremenetsky KV, Klimanov VA (2005) Kazakhstan and Central Asia (plains and foothills). Geol Soc Am Spec Pap 382:139-161. doi:10.1130/ 0-8137-2382-5.139

Andreev M, Kotlov Y, Makarova I (1996) Checklist of lichens and lichenicolous fungi of the Russian Arctic. Bryologist 99:137-169. doi:10.2307/3244545

Ankipovich ES, Shaulo DN, Sedelnikov VP et al (2012) Red data book of Khakassia: rare and endangered species of plant and fungus. Nauka, Novosibirsk

Auestad I, Rydgren K, Økland RH (2008) Scale-dependence of vegetation-environment relationships in semi-natural grasslands. J Veg Sci 19:139-148. doi:10.3170/2007-8-18344

Austrheim G (2002) Plant diversity patterns in semi-natural grasslands along an elevational gradient in southern Norway. Plant Ecol 161:193-205

Bakker ES, Ritchie ME, Olff H, Milchunas DG, Knops JM (2006) Herbivore impact on grassland plant diversity depends on habitat productivity and herbivore size. Ecol Lett 9:780-788. doi:10.1111/j.14610248.2006.00925.x

Bartoń K (2015) MuMIn: multi-model inference. R package version 1.14.0. https://cran.r-project.org/web/ packages/MuMIn/index.html 
Becker T, Brändel M (2007) Vegetation-environment relationships in a heavy metal-dry grassland complex. Folia Geobot 42:11-28. doi:10.1007/BF02835100

Bivand R, Piras G (2015) Comparing implementations of estimation methods for spatial econometrics. J Stat Softw 63:1-36

Bredenkamp GJ, Spada F, Kazmierczak E (2002) On the origin of northern and southern hemisphere grasslands. Plant Ecol 163:209-229. doi:10.1023/A:1020957807971

Breheny P, Burchett W (2015) Visualizing regression models using visreg. https://cran.r-project.org/web/ packages/visreg/index.html

Burnham KP, Anderson DR (2002) Model selection and multimodel inference: a practical informationtheoretic approach, 2nd edn. Springer, New York

Cachovanová L, Hájek M, Fajmonová Z, Marrs R (2012) Species richness, community specialization and soil-vegetation relationships of managed grasslands in a geologically heterogeneous landscape. Folia Geobot 47:349-371. doi:10.1007/s12224-012-9131-3

Chytrý M, Danihelka J, Ermakov N, Hájek M, Hájková P, Kočí M, Kubešová S, Lustyk P, Otýpková Z, Popov D, Roleček J, Řezníčková M, Šmarda P, Valachovič M (2007) Plant species richness in continental southern Siberia: effects of $\mathrm{pH}$ and climate in the context of the species pool hypothesis. Glob Ecol Biogeogr 16:668-678. doi:10.1111/j.1466-8238.2007.00320.x

Chytrý M, Danihelka J, Axmanová I, Božková J, Hettenbergerová E, Li CF, RozbrojováZ Sekulová L, Tichý L, Vymazalová M, Zelený D (2010) Floristic diversity of an eastern Mediterranean dwarf shrubland: the importance of soil pH. J Veg Sci 21:1125-1137. doi:10.1111/j.1654-1103.2010.01212.x

Connor EF, McCoy ED (1979) The statistics and biology of the species-area relationship. Am Nat 113:791-833

Czerepanov SK (1995) Vascular plants of Russia and adjacent states (the former USSR). Cambridge University Press, Cambridge

de Bello F, Lepš J, Sebastià MT (2007) Grazing effects on the species-area relationship: variation along a climatic gradient in NE Spain. J Veg Sci 18:25-34. doi:10.1111/j.1654-1103.2007.tb02512.x

Deák B, Valkó O, Török P, Kelemen A, Miglécz T, Szabó S, Szabó G, Tóthmérész B (2015) Microtopographic heterogeneity increases plant diversity in old stages of restored grasslands. Basic Appl Ecol 16:291-299. doi:10.1016/j.baae.2015.02.008

Dengler J (2005) Zwischen Estland und Portugal-Gemeinsamkeiten und Unterschiede der Phytodiversitätsmuster europäischer Trockenrasen. Tuexenia 25:387-405

Dengler J (2008) Pitfalls in small-scale species-area sampling and analysis. Folia Geobot 43:269-287. doi: $10.1007 / \mathrm{s} 12224-008-9014-9$

Dengler J (2009a) Which function describes the species-area relationship best? A review and empirical evaluation. J Biogeogr 36:728-744. doi:10.1111/j.1365-2699.2008.02038.x

Dengler J (2009b) A flexible multi-scale approach for standardised recording of plant species richness patterns. Ecol Indic 9:1169-1178. doi:10.1016/j.ecolind.2009.02.002

Dengler J, Boch S (2008) Sampling-design effects on properties of species-area curves-a case study from Estonian dry grassland communities. Folia Geobot 43:289-304

Dengler J, Jansen F, Glöckler F, Peet RK, De Cáceres M, Chytrý M, Ewald J, Oldeland J, Lopez-Gonzalez G, Finckh M, Mucina L, Rodwell JS, Schaminée JHJ, Spencer N (2011) The Global Index of Vegetation-Plot Databases (GIVD): a new resource for vegetation science. J Veg Sci 22:582-597. doi:10. 1111/j.1654-1103.2011.01265.x

Dengler J, Todorova S, Becker T, Boch S, Chytrý M, Diekmann M, Dolnik C, Dupré C, Giusso del Galdo GP, Guarino R, Jeschke M, Kiehl K, Kuzemko A, Löbel S, Otýpková Z, Pedashenko H, Peet RK, Ruprecht E, Szabó A, Tsiripidis I, Vassilev K (2012) Database species-area relationships in Palaearctic Grasslands. Biodivers Ecol 4:321-322. doi:10.7809/b-e.00115

Dengler J, Janišová M, Török P, Wellstein C (2014) Biodiversity of Palaearctic grasslands: a synthesis. Agric Ecosyst Environ 182:1-14. doi:10.1016/j.agee.2013.12.015

Drakare S, Lennon JJ, Hillebrand H (2006) The imprint of the geographical, evolutionary and ecological context on species-area relationships. Ecol Lett 9:215-227. doi:10.1111/j.1461-0248.2005.00848.x

Dupré C, Diekmann M (2001) Differences in species richness and life-history traits between grazed and abandoned grasslands in southern Sweden. Ecography 24:275-286. doi:10.1111/j.1600-0587.2001.tb00200.x

Ermakov NB (2012) The higher syntaxa of typical and dry steppes of Southern Siberia and Mongolia. Vestn Novosib Gos Univ Ser Biol Klin Med 10:5-15

Ermakov N, Larionov A, Polyakova M, Pestunov I, Didukh YP (2014) Diversity and spatial structure of cryophytic-steppes of the Minusinskaya intermountain basin in Southern Siberia (Russia). Tuexenia 34:431-446. doi:10.14471/2014.34.019 
Field R, Hawkins BA, Cornell HV, Currie DJ, Diniz-Filho JAF, Guégan JF, Kaufman DM, Kerr JT, Mittelbach GG, Oberdorff T, O’Brien EM, Turner JRG (2009) Spatial species-richness gradients across scales: a meta-analysis. J Biogeogr 36:132-147. doi:10.1111/j.1365-2699.2008.01963.x

Fraser LH, Pither J, Jentsch A, Sternberg M, Zobel M et al (2015) Worldwide evidence of a unimodal relationship between productivity and plant species richness. Science 349:302-305. doi:10.1126/ science.aab3916

Gavlina GB (1954) Climate of Khakasia. In: Britske EV, Gromov LV (eds) Natural conditions and agriculture Khakassian Autonomous Region. Nauka, Moskow, pp 21-29

Gidrometeoizdat (1966-1970) Reference books on the climate of the USSR. Gidrometeoizdat, Leningrad

Gradoboev ND (ed) (1954) Natural conditions and soils cover of left part of Minusinskaya basin. In: Soils of Minusinskaya basin. Moskow, pp 7-183

Grime JP (2002) Plant strategies, vegetation processes, and ecosystem properties, 2nd edn. Wiley, Chichester

Hanke W, Böhner J, Dreber N, Jürgens N, Schmiedel U, Wesuls D, Dengler J (2014) The impact of livestock grazing on plant diversity: an analysis across dryland ecosystems and scales in southern Africa. Ecol Appl 24:1188-1203

Henwood WD (1998) Editorial—the world's temperate grasslands: a beleaguered biome. Parks 8:1-2

Hijmans RJ, Cameron SE, Parra JL, Jones PG, Jarvis A (2005) Very high resolution interpolated climate surfaces for global land areas. Int J Climatol 25:1965-1978. doi:10.1002/joc.1276

Hoekstra JM, Boucher TM, Ricketts TH, Roberts C (2005) Confronting a biome crisis: global disparities of habitat loss and protection. Ecol Lett 8:23-29. doi:10.1111/j.1461-0248.2004.00686.x

Huston MA (2014) Disturbance, productivity, and species diversity: empirism vs. logic in ecological theory. Ecology 95:2382-2396. doi:10.1890/13-1397.1

Ignatov MS, Afonina OM, Ignatova EA, Abolina A, Akatova TV, Baisheva EZ, Bardunov LV, Baryakina EA, Belkina OA, Bezgodov AG, Boychuk MA, Cherdantseva VY, Czernyadjeva IV, Doroshina GY, Dyachenko AP, Fedosov VE, Goldberg IL, Ivanova EI, Jukoniene I, Kannukene L, Kazanovsky SG, Kharzinov ZK, Kurbatova LE, Maksimov AI, Mamatkulov UK, Manakyan VA, Maslovsky OM, Napreenko MG, Otnyukova TN, Partyka LY, Pisarenko OY, Popova NN, Rykovsky GF, Tubanova DY, Zheleznova GV, Zolotov VI (2006) Check-list of mosses of East Europe and North Asia. Arctoa $15: 1-130$

Janišová M, Michalcová D, Bacaro G, Ghisla A (2014) Landscape effects on diversity of semi-natural grasslands. Agric Ecosyst Environ 182:47-58. doi:10.1016/j.agee.2013.05.022

Jarvis P, Linder S (2000) Constraints to growth of boreal forests. Nature 405:904-905. doi:10.1038/ 35016154

Johnson JB, Omland KS (2004) Model selection in ecology and evolution. Trends Ecol Evol 19:101-108. doi:10.1016/j.tree.2003.10.013

Jurasinski G, Retzer V, Beierkuhnlein C (2009) Inventory, differentiation, and proportional diversity: a consistent terminology for quantifying species diversity. Oecologia 159:15-26. doi:10.1007/s00442008-1190-z

Kandalova GT, Lysanova GI (2010) Restoration of steppe pastures of Khakassia. Geogr Nat Resour 4:79-85

Kleiber C, Zeileis A (2008) Applied econometrics with R. Springer, New York

Knapp KA, Briggs MJ, Koelliker KJ (2001) Frequency and extent of water limitation to primary production in a mesic temperate grassland. Ecosystems 4:19-28. doi:10.1007/s100210000057

Kolyago SA (1967) Right-side of Minusinskaya basin (experience of geomorphology analysis for study of history of soils). Nauka, Leningrad

Korolyuk AY (2002) Vegetation. In: Khmelev VA (ed) Steppes of inner Asia. SB RAS Publisher, Novosibirsk, pp 45-94

Kuminova AV, Zvereva GA, Lamanova TG (1976) The main features of development and modern characteristics of steppes. In: Kuminova AV (ed) Vegetation of Khakassia. Nauka, Novosibirsk, pp 95-152

Kuneš P, Svobodová-Svitavská H, Kolář J, Hajnalová M, Abraham V, Macek M, Tkáč P, Szabó P (2015) The origin of grasslands in the temperate forest zone of east-central Europe: long-term legacy of climate and human impact. Quat Sci Rev 116:15-27. doi:10.1016/j.quascirev.2015.03.014

Kuzemko AA, Steinbauer MJ, Becker T, Didukh YP, Dolnik C, Jeschke M, Naqinezhad A, Uğurlu E, Vassilev K, Dengler J (2016) Patterns and drivers of phytodiversity in steppe grasslands of Central Podolia (Ukraine). Biodivers Conserv. doi:10.1007/s10531-016-1060-7

Lavrenko EM, Karamisheva ZV, Nikulina LI (1991) Steppes of central Asia. Nauka, Leningrad

Löbel S, Dengler J, Hobohm C (2006) Species richness of vascular plants, bryophytes and lichens in dry grasslands: the effects of environment, landscape structure and competition. Folia Geobot 41:377-393. doi:10.1007/BF02806555 
Lysenko HM (2007) Comparative phytoindication estimate of forest and steppe ecotopes of Kazatskiy site of Central-Blacksoil reserve. Natl Univ Ser Biol 5:99-105

Makunina NI (2006) Steppes of the Munusinskaya intermountain basin. Turczaninowia 9:112-144

Mathar WP, Kämpf I, Kleinebecker T, Kuzmin I, Tolstikov A, Tupitsin S, Hölzel N (2016) Floristic diversity of meadow steppes in the Western Siberian Plain: effects of abiotic site conditions, management and landscape structure. Biodivers Conserv. doi:10.1007/s10531-015-1023-4

Maurer K, Weyand A, Fischer M, Stöcklin J (2006) Old cultural traditions, in addition to land use and topography, are shaping plant diversity of grasslands in the Alps. Biol Conserv 130:438-446. doi:10. 1016/j.biocon.2006.01.005

Merunková K, Preislerová Z, Chytrý M (2012) White Carpathian grasslands: can local ecological factors explain their extraordinary species richness? Preslia 84:311-325

Merunková K, Preislerová Z, Chytrý M (2014) Environmental drivers of species composition and richness in dry grasslands of northern and central Bohemia, Czech Republic. Tuexenia 34:447-466. doi:10.14471/ 2014.34.017

Moeslund JE, Arge L, Bøcher PK, Dalgaard T, Ejrnæs R, Odgaard MV, Svenning JC (2013) Topographically controlled soil moisture drives plant diversity patterns within grasslands. Biodivers Conserv 22:2151-2166. doi:10.1007/s10531-013-0442-3

Nikolskaya LA (1968) Khakassia. Book Publisher, Krasnoyarsk

Olsson PA, Mårtensson LM, Bruun HH (2009) Acidification of sandy grasslands-consequences for plant diversity. Appl Veg Sci 12:350-361. doi:10.1111/j.1654-109X.2009.01029.x

Palpurina S, Chytrý M, Tzonev R, Danihelka J, Axmanová I, Merunková K, Duchoň M, Karakiev T (2015) Patterns of fine-scale plant species richness in dry grasslands across the eastern Balkan Peninsula. Acta Oecol 63:36-46. doi:10.1016/j.actao.2015.02.001

Pedashenko H, Apostolova I, Boch S, Ganeva A, Janišová M, Sopotlieva D, Todorova S, Ünal A, Vassilev K, Velev N, Dengler J (2013) Dry grassland of NW Bulgarian mountains: first insights into diversity, ecology and syntaxonomy. Tuexenia 33:309-346

Pharo EJ, Kirkpatrick JB, Gilfedder L et al (2005) Predicting bryophyte diversity in grassland and eucalyptdominated remnants in subhumid Tasmania. J Biogeogr 32:2015-2024. doi:10.1111/j.1365-2699.2005. 01366.x

Pokorný P, Chytrý M, Juřičková L, Sádlo J, Novák J, Ložek V (2015) Mid-Holocene bottleneck for central European dry grasslands: did steppe survive the forest optimum in northern Bohemia, Czech Republic? Holocene 25:716-726. doi:10.1177/0959683614566218

Polikarpov NP, Chebakova NM, Nazimova DI (1986) Climate and mountain forests of Siberia. Nauka, Novosibirsk

Polyakova MA (2013) Ecological peculiarities of steppe communities with rare species of Khakassia. Vestn Novosib Gos Univ Ser Biol Klin Med 11:68-74

Polyakova MA, Larionov AV (2012) Peculiarity of steppe communities with participation of alpine species in the Khakassia. Veg Asiat Russ 1(11):86-96

Pykälä J, Luoto M, Heikkinen RK, Kontula T (2005) Plant species richness and persistence of rare plants in abandoned semi-natural grasslands in northern Europe. Basic Appl Ecol 6:25-33. doi:10.1016/j.baae. 2004.10.002

Riccota C, Carranza ML, Avena G (2002) Computing $\beta$-diversity from species-area curves. Basis Appl Ecol 3:15-18. doi:10.1078/1439-1791-00082

Roleček J, Cornej II, Tokarjuk AI (2014) Understanding the extreme species richness of semi-dry grasslands in east-central Europe: a comparative approach. Preslia 86:13-34

Siefert A, Ravenscroft C, Althoff D, Alvarez-Yépiz JC, Carter EC, Glennon KL, Heberling JM, Jo IS, Pontes A, Sauer A, Willis A, Fridley JD (2012) Scale dependence of vegetation-environment relationships: a meta-analysis of multivariate data. J Veg Sci 23:942-951. doi:10.1111/j.1654-1103.2012. 01401.x

Smelansky IE, Tishkov AA (2012) The steppe biome in russia: ecosystem services, conservation status, and actual challenges. In: Werger MJA, van Staalduinen MA (eds) Eurasian steppes. Ecological problems and livelihoods in a changing world. Springer, New York, pp 45-101

Tamme R, Hiiesalu I, Laanisto L, Szava-Kovats R, Pärtel M (2010) Environmental heterogeneity, species diversity and co-existence at different spatial scales. J Veg Sci 21:796-801. doi:10.1111/j.1654-1103. 2010.01185.x

Titlyanova AA (1991) Productivity in grasslands of the USSR. In: McMichael BL, Persson H (eds) Plant roots and their environment. Elsevier Science Publishers, Amsterdam, pp 374-380

Turtureanu PD, PalpurinaS Becker T, Dolnik C, Ruprecht E, Sutcliffe LME, Szabó A, Dengler J (2014) Scale- and taxon-dependent biodiversity patterns of dry grassland vegetation in Transylvania. Agric Ecosyst Environ 182:15-24. doi:10.1016/j.agee.2013.10.028 
Vrahnakis M, Janišová M, Rūsina S, Török P, Venn S, Dengler J (2013) The European Dry Grassland Group (EDGG): stewarding Europe's most diverse habitat type. In: Baumbach H, Pfützenreuter S (eds) Steppenlebensräume Europas-Gefährdung, Erhaltungsmaßnahmen und Schutz. Thüringer Ministerium für Landwirtschaft, Forsten, Umwelt und Naturschutz, Erfurt, pp 417-434

Wal R, Pearce ISK, Brooker RW (2005) Mosses and the struggle for light in a nitrogen-polluted world. Oecologia 142:159-168. doi:10.1007/s00442-004-1706-0

Walter H, Breckle SW (1986) Ökologie der Erde-Band 3: Spezielle Ökologie der gemäßigten und arktischen Zonen Euro-Nordasiens. Fischer, Stuttgart

Wesche K, Treiber J (2012) Abiotic and biotic determinants of steppe productivity and performance-a view from Central Asia. In: Werger MJA, van Staalduinen MA (eds) Eurasian steppes. Ecological problems and livelihoods in a changing world. Springer, New York, pp 3-43

Wilson JB, Peet RK, Dengler J, Pärtel M (2012) Plant species richness: the world records. J Veg Sci 23:796-802. doi:10.1111/j.1654-1103.2012.01400.x 